\title{
Pengembangan Perangkat Pembelajaran dengan Menggunakan Model Discovery Learning dalam Rangka Memfasilitasi Kemampuan Komunikasi Matematis Pada Materi Bangun Datar Kelas VII SMP
}

\author{
Indah Prestika $^{1}$, Sehatta Saragih ${ }^{2}$, Putri Yuanita ${ }^{3}$ \\ 1,2,3 Program Pasca Sarjana Pendidikan Matematika, Universitas Riau, Jl. H. R. Soebrantas, Riau \\ prestika11@gmail.com
}

\begin{abstract}
This study aims to develop learning tools that use discovery learning models in order to facilitate mathematical communication skills on flat-shape materials for grade VII students. The study is intended to develop learning tools that use the ADDIE model made up of analyze, design, development, implementation, evaluation. Testing carried out the two stages of validation and the small group test. The validation stage was carried out on September 3, 2020, while the small group trial stage was carried out on October 2,2020. Testing subject for this study made up of 12 seventh graders. The instrument used consisted of validation sheet and learners rensponse sheets. Research shows that develop learning tools have meth both the validity and the practicality. The results showed that the learning tools developed had met the validity and practicality aspects, namely (1) the validity results showed that the learning tools developed were in the very valid category with a value on the syllabus of 91.67, the RPP was 88.21, the LKPD was 91.21, (2) the results of small group trials showed that the mathematics learning device developed in the very practical category was 88.68 .
\end{abstract}

Keywords: Learning Device Development, Discovery Learning, Communication Skills

\begin{abstract}
Abstrak
Penelitian ini bertujuan untuk mengembangkan perangkat pembelajaran yang menggunakan model discovery learning dalam rangka memfasilitasi kemampuan komunikasi matematis pada materi bangun datar untuk peserta didik kelas VII. Jenis penelitian ini adalah penelitian pengembangan menggunakan model ADDIE yang terdiri atas analyze, design, development, Implementation, Evaluation. Ujicoba dilaksanakan dua tahap, yaitu validasi dan ujicoba kelompok kecil. Tahap validasi dilakukan pada tanggal 3 September 2020, sedangkan tahap ujicoba kelompok kecil dilakukan pada tanggal 2 Oktober 2020. Subjek ujicoba penelitian ini terdiri dari 12 orang peserta didik kelas VII. Instrumen yang digunakan terdiri atas lembar validasi dan lembar angket respon peserta didik. Hasil penelitian menunjukkan bahwa perangkat pembelajaran yang dikembangkan telah memenuhi aspek validitas dan kepraktisan, yakni (1) hasil validitas menunjukkan bahwa perangkat pembelajaran yang dikembangkan pada kategori sangat valid dengan nilai pada silabus sebesar 91,67, pada RPP sebesar 88,21, pada LKPD sebesar 91,21, (2) hasil ujicoba kelompok kecil menunjukkan perangkat pembelajaran matematika yang dikembangkan pada kategori sangat praktis sebesar 88,68 .
\end{abstract}

Kata kunci: Pengembangan Perangkat Pembelajaran, Discovery Learning, Kemampuan Komunikasi

Copyright (c) 2021 Indah Prestika, Sehatta Saragih, Putri Yuanita

$\triangle$ Corresponding author: Indah Prestika

Email Address: prestika11@gmail.com (Jl. H. R. Soebrantas, Riau)

Received 05 November 2020, Accepted 29 Desember 2020, Published 31 Maret 2021

\section{PENDAHULUAN}

Seiring dengan perkembangan zaman, pendidikan juga mengalami perkembangan pesat. Dalam kurikulum dinyatakan bahwa pendidikan bertujuan untuk mengembangkan potensi peserta didik agar memiliki kecerdasan, berakhlak mulia serta memiliki keterampilan yang diperlukan sebagai anggota masyarakat dan warga negara. Terkait dengan tujuan tersebut, maka dilakukan reformasi dalam sistem pendidikan hingga ke proses pembelajarannya, misalnya perubahan paradigma pendidikan dari yang teacher centre ke student centre dan perubahan-perubahan lainnya. Sebelum perubahan paradigma 
tersebut, peserta didik diposisikan sebagai objek pembelajaran dan guru merupakan sumber utama belajar, sehingga peserta didik sangat tergantung pada sosok guru.

Matematika memiliki peran sebagai bahasa simbolik yang memungkinkan terwujudnya komunikasi secara cermat dan tepat. Melalui komunikasi yang baik dapat membantu peserta didik membangun pemahamannya terhadap ide-ide matematika. Matematika tidak hanya sekedar alat bantu berfikir tetapi matematika juga sebagai wahana komunikasi antar peserta didik dan guru, serta alat untuk mengkomunikasikan berbagai ide dengan jelas, akurat, dan ringkas. Gagasan yang di komunikasikan dengan bahasa matematika justru lebih praktis, sistematis, dan efisien (Nuraeni \& Luritawaty, 2018).

Sejalan dengan pernyataan di atas, dalam Permendikbud no 58 Tahun 2014 tentang kurikulum 2013, dinyatakan tujuan pendidikan matematika salah satunya yaitu mampu mengkomunikasikan gagasan, penalaran serta mampu menyusun bukti matematika dengan menggunakan kalimat lengkap, simbol, tabel, diagram, atau media lain untuk memperjelas keadaan atau masalah. Berdasarkan tujuan pembelajaran matematika diharapkan proses pembelajaran matematika mampu mengembangkan kemampuan komunikasi peserta didik.

Berdasarkan hasil survey, hasil belajar matematika di Indonesia masih tergolong sangat rendah. Hadi (2018) menyatakan bahwa hasil survei TIMSS menunjukkan bahwa kemampuan peserta didik Indonesia dalam pembelajaran matematika masih sangat jauh dari rata-rata internasional. Indonesia termasuk salah satu negara yang menjadi objek TIMSS dari tahun 1999, 2003 2007, 2011 dan 2015. Rata-rata skor prestasi matematika peserta didik Indonesia pada tiga periode tersebut masih rendah, pencapaian ini menunjukkan bahwa secara rata-rata siswa Indonesia hanya mampu mengenali sejumlah fakta dasar tetapi belum mampu mengkomunikasikan, mengaitkan berbagai topik, apalagi menerapkan konsep-konsep yang kompleks dan abstrak dalam matematika. Sehingga termasuk kategori Low International Benchmark. Studi ini selalu menjadi acuan ukuran kemampuan peserta didik di indonesia yang dibandingkan dengan negara-negara lainnya. Hasil survei TIMSS tahun 2015, Indonesia berada di peringkat 44 dari 49 negara. Berdasarkan hasil yang diperoleh tersebut menunjukkan rendahnya prestasi belajar matematika peserta didik SMP di Indonesia.

Gejala rendahnya kemampuan komunikasi matematis di SMP juga dapat dilihat dari hasil tes yang diberikan kepada peserta didik. Hasil tes yang diberikan pada peserta didik kelas VII SMP Negeri 5 Kampar Kiri menunjukkan bahwa kemampuan komunikasi matematis peserta didik masih rendah. Peserta didik mengalami kesulitan dalam menyelesaikan soal yang mengukur kemampuan komunikasi matematis berikut ini. Berikut ini merupakan salah satu soal dan jawaban peserta didik.

Reni mempunyai kamar yang berukuran $6 \mathrm{~m}$ x $3 \mathrm{~m}$. Reni berencana akan memasang ubin kamarnya. Ukuran ubin yang reni pilih adalah $60 \times 60$.

a. Buatlah sketsa lantai kamar reni?

b. Buatlah model matematika dari masalah tersebut?

c. Berapa jumlah ubin yang akan reni beli? 
Pengembangan Perangkat Pembelajaran dengan Menggunakan Model Discovery Learning dalam Rangka Memfasilitasi Kemampuan Komunikasi Matematis Pada Materi Bangun Datar Kelas VII SMP, Indah Prestika, Sehatta Saragih, Putri Yuanita

Gambar 1. Soal Tes Kemampuan Komunikasi

Jawaban Soal Tes Kemampuan Komunikasi:

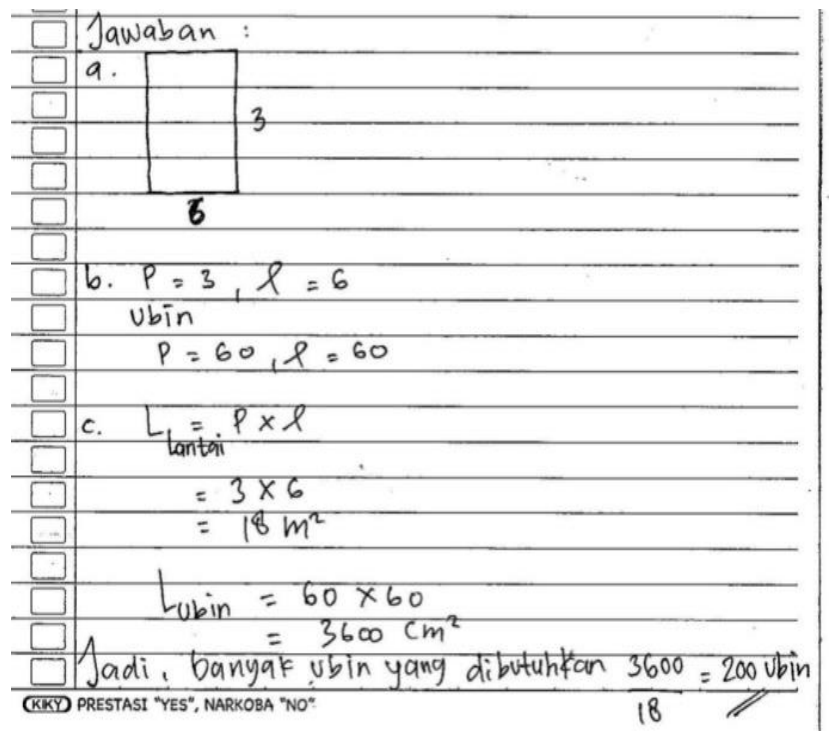

Gambar 2. Jawaban Soal Tes Kemampuan Komunikasi

Dari hasil jawaban soal tes kemampuan komunikasi matematis, setelah dilakukan tes kepada peserta didik dengan menggunakan instrumen soal seperti yang dimuat sebelumnya, peserta didik yang dapat mengerjakan soal sesuai dengan indikator komunikasi matematis, seperti (1) Drawing, jawaban peserta didik tersebut menunjukkan bahwa peserta didik tidak dapat menggambarkan soal tersebut ke dalam model matematika. Hanya $12 \%$ peserta didik yang sudah dapat merefleksikan benda-benda nyata, gambar dan diagram dalam ide matematika untuk indikator (2) Written Text, jawaban peserta didik tersebut menunjukkan bahwa peserta didik juga tidak dapat membedakan panjang dan lebar yang telah diketahui, serta peserta didik lupa mengubah satuan luas ke $\mathrm{cm}$ sehingga hasil perhitungan banyaknya ubin yang diperoleh tidak tepat. Hanya $14 \%$ yaitu hanya beberapa peserta didik yang dapat memberikan jawaban dengan menggunakan bahasa sendiri, kemudian membuat model situasi atau persoalan menggunakan model matematika dalam bentuk tulisan, namun belum dapat menjelaskan dan membuat pertanyaan tentang materi matematika yang telah dipelajari seperti yang diperoleh dari data di atas, begitu juga sebaliknya, namun untuk indikator (3) Mathematical Expression, sedikit lebih tinggi dari indikator lain, yaitu diperoleh 35\% peserta didik yang sudah bisa mengekspresikan konsep matematika dengan menyatakan peristiwa sehari-hari dalam bahasa atau simbol matematika.

Fakta ini menunjukkan bahwa kemampuan komunikasi peserta didik belum optimal, dan salah satu proses pembelajaran yang dikelola guru. Kecenderungan guru menjadikan peserta didik pasif, sehingga 
mereka tidak berkesempatan mengungkapkan ide-ide matematikanya yang berdampak pada kemampuan komunikasi matematis. Berdasarkan hasil penelitian yang dilakukan oleh Suharno et al. (2019) memperlihatkan bahwa kebanyakan peserta didik masih belum mampu menghubungkan ide-ide yang telah didapatkannya sehingga mereka tidak dapat mencari penyelesaian dari permasalahan tersebut. Peserta didik masih kesulitan dalam menyatakan ide dari soal serta menyusunnya menjadi sebuah penyelesaian secara lengkap dan logis.

Selanjutnya berdasarkan hasil penelitian yang dilakukan oleh Kaselin et al. (2013) diketahui bahwa kemampuan komunikasi matematis peserta didik masih rendah.Masih banyak peserta didik yang tidak mampu menghubungkan permasalahan yang dihadapi dengan konteks kejadian yang ada dalam kehidupan nyata, tidak mampu mengolah data atau informasi pada soal, dan kesulitan di dalam menerapkan pengetahuan yang dipelajari sebelumnya.Dari beberapa fakta diatas, terlihat bahwa kemampuan komunikasi dalam pembelajaran matematika masih rendah.Upaya untuk meningkatkan kemampuan komunikasi matematis siswa yaitu dengan mendorong pesrta didik melakukan aktivitasaktivitas seperti menulis, menggambar, membaca, dan mengkontrusikan sendiri ide-ide matematis.

Untuk memfasilitasi peserta didik membangun kemampuan komunikasi, perlu penerapan strategi pembelajaran yang tepat. Suherman yang menyatakan bahwa pada proses pembelajaran matematika siswa harus berperan aktif dan ditempatkan sebagai subjek pembelajaran (Mukaromah et al., 2018). Dalam upaya perbaikan proses pembelajaran telah dinyatakan dalam kurikulum 2013 bahwa dalam pelaksanaan pembelajaran menggunakan pendekatan saintifik (ilmiah).

Salah satu model pembelajaran yang direkomendasikan dalam Kurikulum 2013 yang dapat digunakan adalah discovery Learning. Menurut Bruner, discovery learning merupakan proses belajar memberikan kesempatan pada peserta didik untuk menemukan suatu konsep, teori, aturan, atau pemahaman melalui contoh-contoh yang dijumpai dalam kehidupannya (Kemendikbud, 2013). Dengan model penemuan diharapkan peserta didik tidak hanya menghafal konsep matematika yang dipelajari, tetapi membangun sendiri konsep tersebut sehingga akan lebih mantap penguasaan konsep matematikanya (Yuliyanto \& Jailani, 2014).

Dalam rangka menerapkan discovery learning dalam pembelajaran, maka diperlukan perangkat pembelajaran yang baik. Dalam kurikulum 2013, dinyatakan bahwa perangkat pembelajaran merupakan kebutuhan mendasar yang harus dimiliki seorang guru sebelum memulai proses pembelajaran. Seorang guru harus mempersiapkan perencanaan pembelajaran yang dirancang dalam bentuk silabus dan rencana pelaksanaan pembelajaran (RPP) yang mengacu pada standar isi (Permendikbud No 65 tahun 2013). Seorang guru harus mempersiapkan perencanaan pembelajaran yang dirancang dalam bentuk silabus dan rencana pelaksanaan pembelajaran (RPP) yang mengacu pada standar isi (Permendikbud No 65 tahun 2013).

Perangkat pembelajaran sangat penting, karena merupakan acuan guru untuk melaksanakan kegiatan pembelajaran supaya lebih terarah dan sistematis. Perangkat pembelajaran adalah hal-hal yang harus dipantau sehingga pelaksanaan pembelajaran lebih terarah untuk mencapai kompetensi yang 
Pengembangan Perangkat Pembelajaran dengan Menggunakan Model Discovery Learning dalam Rangka Memfasilitasi Kemampuan Komunikasi Matematis Pada Materi Bangun Datar Kelas VII SMP, Indah Prestika, Sehatta Saragih, Putri Yuanita

diharapkan (Ferawati, 2020). Hasil penelitian tentang perangkat pembelajaran yang digunakan guru di sekolah belum sesuai dengan kurikulum 2013 Kartika et al. (2020) menyatakan perangkat pembelajaran yang digunakan guru seperti RPP yang disusun belum mengacu pada komponen RPP yang dikemukakan Permendikbud No 22 tahun 2016 contoh IPK yang belum menggunakan kata kerja operasional, rincian kegiatan pembelajaran belum sesuai dengan model pembelajaran yang digunakan, pendekatan saintifik belum terlihat dan langkah-langkah model pembelajaran yang digunakan belum terlihat pada kegiatan pembelajaran.

Berdasarkan observasi yang dilakukan pada salah satu guru di SMPN 37 Pekanbaru diperoleh informasi bahwa kegiatan pembelajaran yang dinyatakan dalam RPP yang dikembangkan guru belum mampu memfasilitasi peserta didik dalam mengkonstruksi sendiri pengetahuanya dalam membangun kemampuan komunikasinya. Selain itu LKPD yang digunakan belum mampu memfasilitasi peserta didik secara maksimal dalam mengembangkan ide dan pola pikirnya. LKPD yang digunakan cenderung menyajikan konsep maupun prinsip tanpa adanya proses untuk memperolehnya sehingga siswa tidak terbiasa menggunakan keterampilan berpikir dalam menemukan konsep dan memecahkan suatu masalah secara ilmiah. LKPD matematika yang diberikan berisi ringkasan materi, contoh, dan soal latihan. Peserta didik hanya dituntut untuk dapat menyelesaikan soal latihan. Hal ini belum sesuai dengan makna LKPD yang sesungguhnya yaitu sarana untuk menyampaikan konsep pada siswa yang berisi petunjuk untuk menemukan konsep materi.

Berdasarkan hasil observasi dan analisis terkait perangkat pembelajaran, diperoleh bahwa dapat memfasilitasi aktivitas belajar siswa dalam membangun kemampuan komunikasi matematis. Sehubungan dengan ini maka perlu upaya pengembangan perangkat yang sesuai dengan kurikulum 2013 dan dapat memberikan kesempatan peserta didik untuk mengembangkan kemampuan komunikasinya. Perangkat pembelajaran yang baik dan berkualitas adalah perangkat pembelajaran yang memenuhi kriteria valid, praktis dan efektif. Dari pernyataan Akker disimpulkan bahwa kriteria kualitas suatu perangkat pembelajaran yaitu kevalidan (validity), kepraktisan (practically), dan keefektifan (effectiveness) (Rochmad, 2012).

\section{METODE}

Penelitian ini merupakan penelitian pengembangan dengan menggunakan desain ADDIE dan produk yang dihasilkan yaitu silabus, Rencana Pelaksanaan Pembelajaran (RPP) dan Lembar Kegiatan Peserta Didik (LKPD). Adapun langkah penelitian pengembangan ADDIE dalam penelitian ini jika disajikan dalam bentuk bagan adalah sebagai berikut:

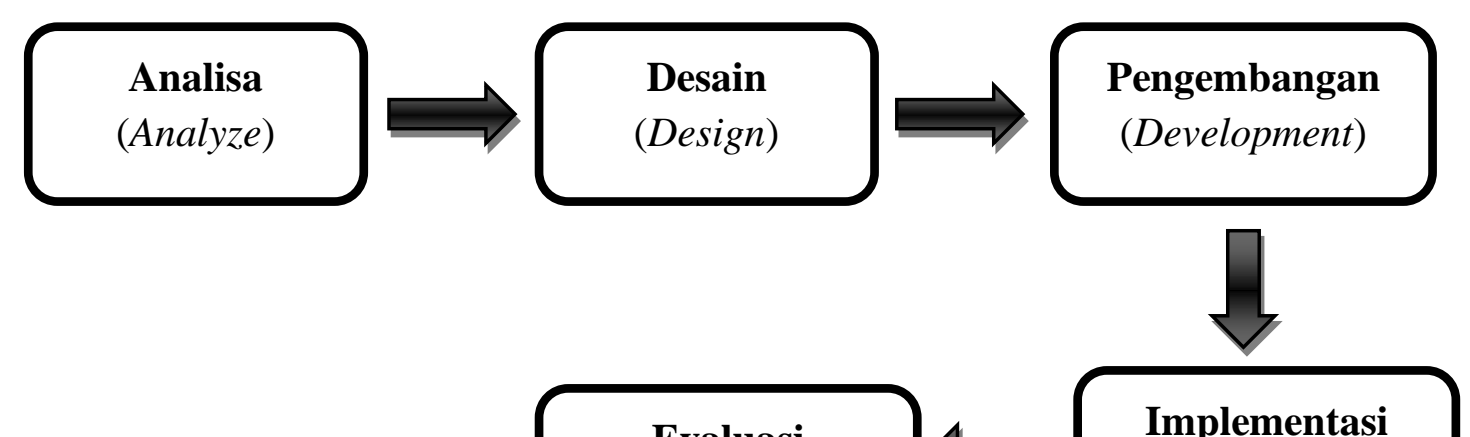


Gambar 3. Model ADDIE (modifikasi dari Sugiyono,2015)

Subjek uji coba dalam penelitian ini adalah peserta didik kelas VII. Kegiatan penelitian pada tahap analisis adalah (1) Analisis kinerja yang tujuannya untuk pengumpulan informasi mengenai permasalahan yang terdapat dalam pembelajaran matematika di sekolah yang terkait dengan pengembangkan perangkat dan kondisi proses pembelajaran; (2) Analisis kebutuhan dilakukan untuk mengkaji masalah dasar yang dihadapi guru dalam proses pembelajaran, khususnya dalam topik bangun datar. Pada tahapan rancangan (design), didasarkan pada hasil analisis kinerja dan analisis kebutuhan yaitu 1) Pemilihan format, 2) Rancangan awal, merancang perangkat pembelajaran berupa silabus, RPP, LKPD berdasarkan format yang telah dibuat. Pada tahap pengembangan (development) kegiatan penelitian adalah mengembangkan perangkat pembelajaran dan validasi ahli. Uji ahli dilakukan untuk menentukan kevalidan dari hasil rancangan awal perangkat pembelajaran. Perangkat pembelajaran yang telah divalidasi kemudian direvisi berdasarkan saran dari validator. Pada tahap implementasi (implementation) perangkat pembelajaran yang telah dikoreksi diujicobakan dilapangan untuk mengetahui kepraktisan dari LKPD yang dikembangkan.

Teknik pengumpulan data penelitian ini menggunakan lembar penilaian perangkat pembelajaran (valid) dan angket respon peserta didik. Data yang diproses kemudian dianalisis, yakni analisis data dilakukan untuk mengetahui kevalidan dan kepraktisan perangkat pembelajaran yang dikembangkan. Perangkat pembelajaran dikatakan valid jika hasil analisis yang telah dilakukan rata-rata memenuhi kategori valid. Menurut Akbar (2013), perangkat pembelajaran dikatakan valid dapat digunakan jika persentase validasi dan kepraktisan lebih dari 70\%. Analisis kevalidan perangkat pembelajaran yang dikembangkan memenuhi kriteria kevalidan. Adapun kriteria kevalidan perangkat pembelajaran dimuat pada Tabel 1 .

Tabel 1. Kriteria Validitas Perangkat Pembelajaran

\begin{tabular}{|l|l|}
\hline \multicolumn{1}{|c|}{ Interval } & \multicolumn{1}{c|}{ Kategori } \\
\hline $85,01 \%-100,00 \%$ & Sangat valid, atau dapat digunakan tanpa revisi \\
\hline $70,01 \%-85,00 \%$ & Cukup valid, atau dapat digunakan namun perlu revisi kecil \\
\hline $50,01 \%-70,00 \%$ & Kurang valid, disarankan tidak dipergunakan karena perlu revisi besar \\
\hline $01,00 \%-50,00 \%$ & Tidak valid, atau tidak boleh dipergunakan. \\
\hline
\end{tabular}

Sumber: Akbar (2013)

Analisis kepraktisan bertujuan untuk mengetahui apakah perangkat pembelajaran yang dikembangkan memenuhi kriteria kepraktisan. Adapun kriteria kepraktisan perangkat pembelajaran dimuat pada Tabel 2. 
Pengembangan Perangkat Pembelajaran dengan Menggunakan Model Discovery Learning dalam Rangka Memfasilitasi Kemampuan Komunikasi Matematis Pada Materi Bangun Datar Kelas VII SMP, Indah Prestika, Sehatta Saragih, Putri Yuanita

Tabel 2. Kriteria Praktikalitas Perangkat Pembelajaran

\begin{tabular}{|c|l|l|}
\hline No & \multicolumn{1}{|c|}{ Tingkat Pencapaian } & Tingkat Validitas dan Praktikalitas \\
\hline 1 & $85,01 \%-100,00 \%$ & Sangat praktis \\
\hline 2 & $70,01 \%-85,00 \%$ & Praktis \\
\hline 3 & $50,01 \%-70,00 \%$ & Kurang praktis \\
\hline 4 & $01,00 \%-50,00 \%$ & Tidak praktis \\
\hline
\end{tabular}

Sumber: Akbar (2013)

\section{HASIL DAN DISKUSI}

Pada Penelitian ini menghasilkan perangkat pembelajaran berupa silabus, RPP, dan LKPD untuk peserta didik SMP kelas VII pada materi bangun datar, yang menggunakan model discovery learning. Perangkat pembelajaran yang dikembangkan menggunakan model ADDIE dengan lima tahapan yaitu Analyze, Design, Development, Implementation, Evaluation. Hasil penelitian dari tahap analyze ini meliputi, pada tahap analisis kinerja, untuk memperoleh data maka peneliti mengkaji kurikulum yang berlaku yaitu kurikulum 2013, melakukan analisis terhadap perangkat pembelajaran yang dibuat guru di sekolah dan masalah yang dihadapi di sekolah dengan teknik wawancara. Aspek wawancara terdiri dari keterlaksanaan Kurikulum 2013, keterlibatan guru dalam menyusun perangkat pembelajaran, mengembangkan IPK, merumuskan tujuan pembelajaran, proses pembelajaran, KKM dan menyusun penilaian hasil belajar.

Pada tahap analisis kebutuhan, untuk memperoleh data maka peneliti melakukan observasi peserta didik pada saat proses pembelajaran matematika, melakukan wawancara, dan memberikan soal terkait KKM. Peneliti melakukan observasi, tes KKM dan wawancara dengan peserta didik kelas VII SMP Pekanbaru. Soal KKM diberikan kepada peserta didik yang telah mempelajari materi Bangun Datar. Observasi, tes KKM dan wawancara dilakukan untuk melihat aktivitas serta KKM peserta didik terhadap mata pelajaran matematika.

Pada tahap perancangan (design), untuk memperoleh data maka peneliti melakukan kegiatan diantaranya memilih format untuk perangkat pembelajaran matematika yang dikembangkan berupa Silabus, RPP dan LKPD, selanjutnya peneliti mendesain rancangan awal yang sesuai dengan format yang telah dipilih. Silabus dan RPP dirancang berpedoman pada komponen silabus dan RPP yang terdapat pada Permendikbud Nomor 22 tahun 2016.

Hasil analisis perangkat pembelajaran menunjukkan silabus yang dirancang terdiri dari komponen KD, materi pembelajaran, dan kegiatan pembelajaran untuk delapan pertemuan pada materi bangun datar yang memuat komponen identitas, KI, KD, materi pembelajaran, indikator pencapaian kompetensi, kegiatan pembelajaran, penilaian, alokasi waktu, dan sumber belajar. Peneliti merancang RPP pada materi bangun datar untuk delapan kali pertemuan yang masing-masing memuat komponen identitas; KI; KD dan indikator pencapaian kompetensi; tujuan pembelajaran; materi pembelajaran; pedekatan, model, dan metode pembelajaran; media, alat, dan sumber belajar; langkah-langkah pembelajaran; dan penilaian. Peneliti merancang LKPD dengan menggunakan model discovery learning, sehingga dapat memfasilitasi peserta didik dalam melakukan penyelidikan yang terdiri dari 
bagian sampul, isi LKPD dan latihan soal awal berisi sampul LKPD, bagian isi berisi lembar aktivitas, dan bagian kesimpulan/ akhir berisi latihan soal.

Pada tahap pengembangan (development) perangkat pembelajaran yang sudah di rancang berdasarkan format kemudian dikembangkan. Kegiatan pembelajaran pada silabus dan RRP disusun lebih rinci dengan menguraikan secara lebih jelas tentang langkah-langkah discovery learning yaitu stimulation, problem statement, data collection, data processing, generalization. Berikut contoh kegiatan pembelajaran pada silabus dan RPP yang telah dikembangkan pada gambar 4 dan 5 .

\begin{tabular}{|c|c|c|c|c|}
\hline Kompetensi Dasar & $\begin{array}{c}\text { Materi } \\
\text { Pokok/ } \\
\text { Materi } \\
\text { Pembelajaran }\end{array}$ & $\begin{array}{c}\text { Indikator Pencapaian } \\
\text { Kompetensi }\end{array}$ & Kegiatan Pembelajaran & Penilaian \\
\hline 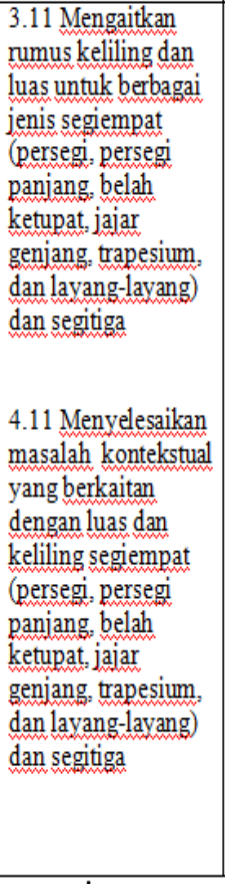 & Persegi & $\begin{array}{l}3.11 .1 \text { Mengidentifikasi } \\
\text { keliling dan luas perseg } \\
\text { panjang berdasarkan sifat- } \\
\text { sifat persegi } \\
3.11 .2 \text { Menjelaskan sifat- } \\
\text { sifat persegi ditinjau dari } \\
\text { sisi, diagonal dan } \\
\text { sudutnya } \\
3.11 .3 \text { Menemukan rumus } \\
\text { keliling dan luas persegi } \\
4.11 .1 \text { Menerapkan } \\
\text { konsep keliling dan luas } \\
\text { perseg } \\
\text { menyelesaikan masalah } \\
\text { yang berkaitan dengan } \\
\text { kehidupan sehari-hari }\end{array}$ & 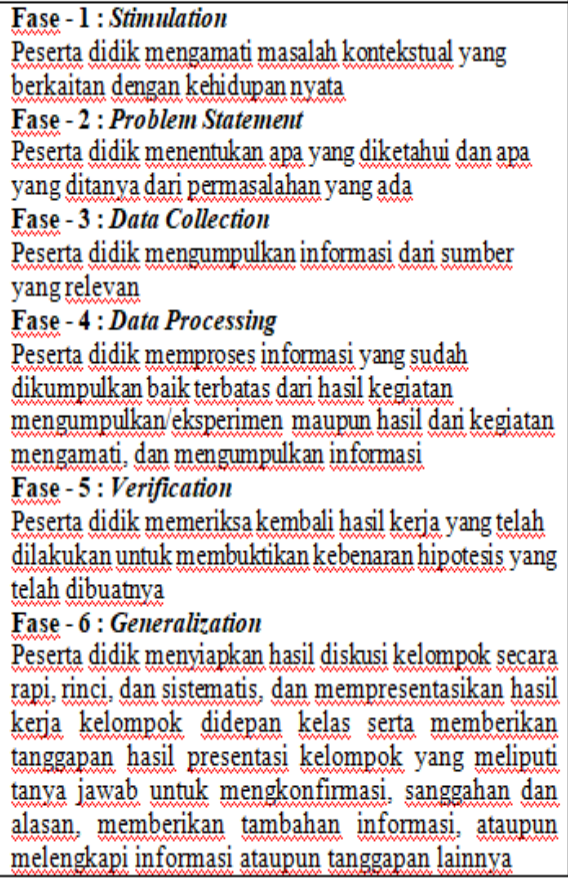 & $\begin{array}{l}1 . \\
\text { Pengetahuan } \\
\text { Tes Tertulis } \\
\text { Uraian } \\
2 . \\
\text { Keteram pilan } \\
\text { Tes } \\
\text { Tes Tertulis } \\
\text { Uraian }\end{array}$ \\
\hline
\end{tabular}

Gambar 4. Gambaran Silabus

LKPD dikembangkan berdasarkan langkah model discovery learning dan indikator kemampuan komunikasi matematis. Hasil rancangan LKPD terdiri dari sampul, isi LKPD dan latihan soal. Sampul LKPD dirancang memuat judul, kotak penulisan nama, petunjuk dan tujuan pembelajaran. Sampul LKPD juga dihiasi dengan gambar yang sesuai dengan materi pelajaran. Bagian sampul LKPD dibuat dengan tampilan yang sama, namun dengan warna dan gambar yang berbeda. Bagian isi LKPD disusun berdasarkan langkah-langkah model discovery learning yaitu stimulation, problem statement, data collection, data processing, generalization dan indikator kemampuan komunikasi matematis. Pada bagian isi LKPD dirancang dengan kegiatan yang sama, namun disesuaikan dengan materi yang dipelajari untuk setiap pertemuannya. Berikut ini contoh bagian sampul dan bagian isi LKPD yang telahdikembangkan. 


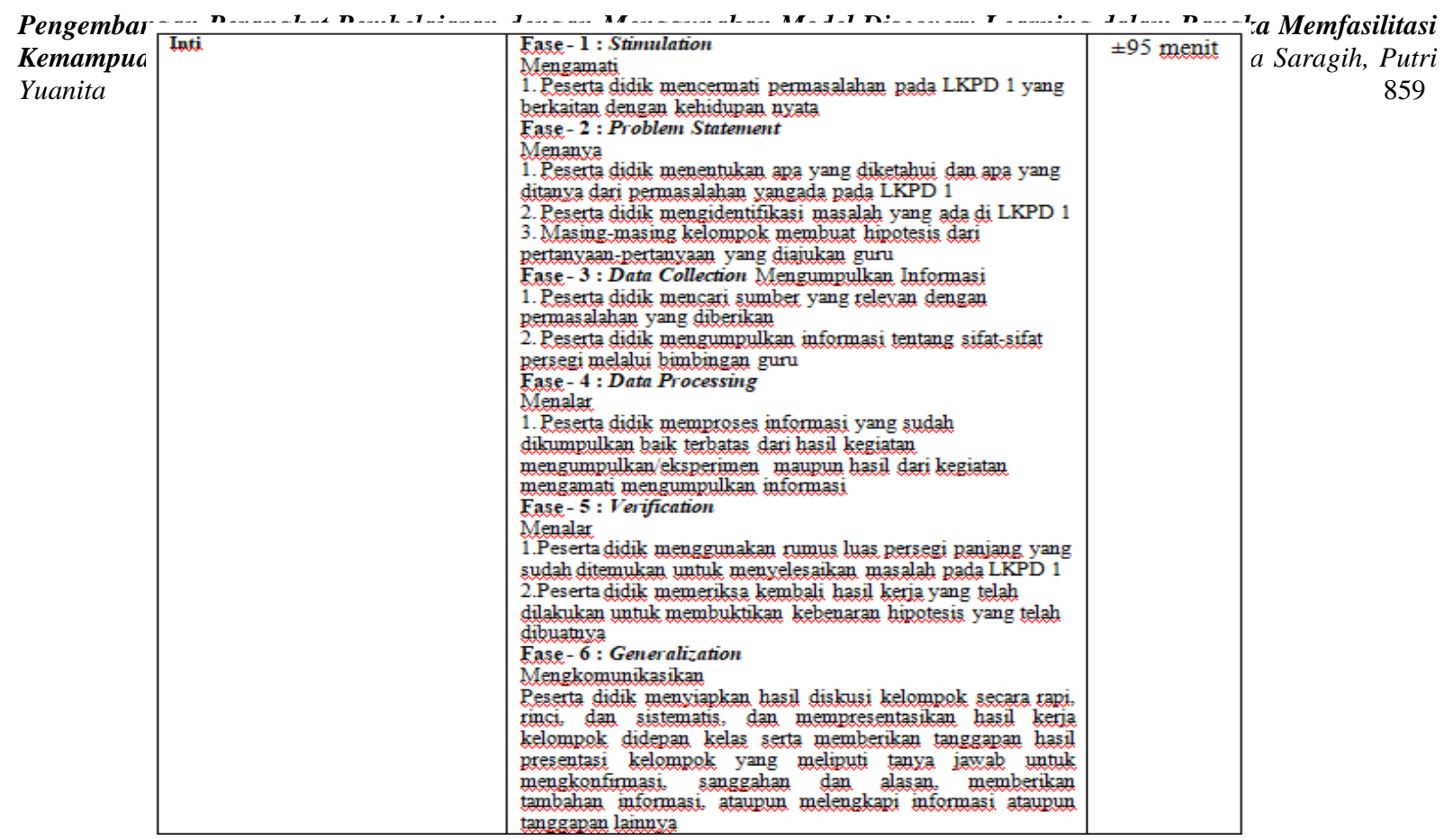

Gambar 5. Gambaran RPP
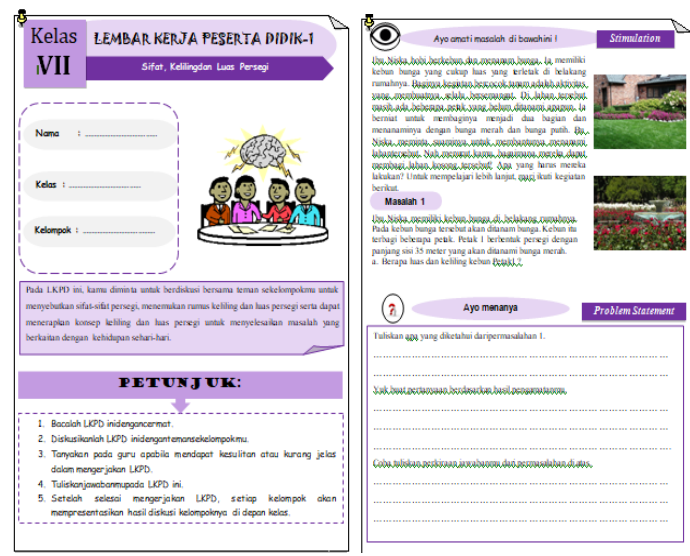

Gambar 3. Bagian sampul dan isi LKPD

Rancangan LKPD pada Gambar 3 merupakan rancangan bagian sampul dan bagian isi LKPD yaitu langkah stimulation dan problem statement materi sifat, keliling dan luas persegi. Pada langkah stimulation diberikan sebuah permasalahan dalam kehidupan sehari-hari yang berbentuk soal cerita. Pada langkah stimulation, peserta didik mengamati masalah kontekstual yang disajikan berupa kolom "ayo amati masalah dibawah ini" terkait dengan keliling dan luas persegi. Pada langkah problem statement terdapat kegiatan menanya dimana peserta didik menentukan apa yang diketahui dan apa yang ditanya dari permasalahan yang ada pada LKPD.

Perangkat pembelajaran yang sudah dikembangkan di validasi kepada validator serta melakukan uji coba terhadap perangkat yang telah disusun. Saran-saran dari validator tersebut akan dijadikan bahan untuk merevisi perangkat yang telah disusun. Hasil revisi tersebut merupakan perangkat pembelajaran yang telah memenuhi kriteria valid. Perangkat pembelajaran yang telah dinyatakan valid diuji coba terhadap peserta didik. Pada penelitian ini, uji coba dilakukan hanya sampai pada uji coba 
kelompok kecil untuk melihat kepraktisan perangkat pembelajaran yang dikembangkan. Uji coba ini dilakukan terhadap 12 orang peserta didik kelas VII SMP Dharma Yudha Pekanbaru. Rata-rata penilaian yang diberikan oleh tiga orang validator terhadap perangkat pembelajaran yang dikembangkan berupa silabus, RPP dan LKPD serta soal dapat dilihat pada Tabel 3 sampai Tabel 6 berikut.

Tabel 3. Hasil Validasi Silabus

\begin{tabular}{|c|l|c|c|}
\hline No & Validator & Nilai Validitas & Kriteria \\
\hline 1 & Validator I & $95 \%$ & Sangat Valid \\
\hline 2 & Validator II & $85 \%$ & Valid \\
\hline 3 & Validator III & $95 \%$ & Sangat Valid \\
\hline & Rata-rata & $91,67 \%$ & Sangat Valid \\
\hline
\end{tabular}

Sumber: Olahan data, 2020

Berdasarkan Tabel 3 diperoleh bahwa rata-rata keseluruhan terhadap penilaian silabus sebesar 91,67\%. Berdasarkan kriteria penilaian validitas, penilaian silabus berdasar pada kriteria "sangat valid". Artinya silabus layak untuk di uji coba, akan tetapi validator tetap memberikan masukan dan saran agar silabus yang dikembangkan menjadi lebih baik.

Tabel 4. Hasil Validasi RPP

\begin{tabular}{|l|l|l|l|l|l|l|l|l|}
\hline \multirow{2}{*}{ Validator } & \multicolumn{7}{|c|}{ RPP } \\
\cline { 2 - 9 } & RPP 1 & RPP 2 & RPP 3 & RPP 4 & RPP 5 & RPP 6 & RPP 7 & RPP 8 \\
\hline I & $86,58 \%$ & $86,58 \%$ & $86,58 \%$ & $86,58 \%$ & $86,58 \%$ & $86,58 \%$ & $86,58 \%$ & $86,58 \%$ \\
\hline II & $85,97 \%$ & $85,97 \%$ & $85,97 \%$ & $85,97 \%$ & $85,97 \%$ & $85,97 \%$ & $85,97 \%$ & $85,97 \%$ \\
\hline III & $92,07 \%$ & $92,07 \%$ & $92,07 \%$ & $92,07 \%$ & $92,07 \%$ & $92,07 \%$ & $92,07 \%$ & $92,07 \%$ \\
\hline Rata-rata & $88,21 \%$ & $88,21 \%$ & $88,21 \%$ & $88,21 \%$ & $88,21 \%$ & $88,21 \%$ & $88,21 \%$ & $88,21 \%$ \\
\hline
\end{tabular}

Sumber: Olahan data, 2020

Hasil validasi menunjukkan bahwa RPP untuk delapan pertemuan berdasar pada kriteria sangat valid dengan persentase rata-rata $88,21 \%$. Ketiga validator menyimpulkan bahwa RPP dapat digunakan, akan tetapi validator tetap memberikan masukan dan saran agar RPP yang dikembangkan lebih baik lagi. Penilaian dari validator berupa koreksi, kritik, dan saran yang digunakan sebagai bahan pertimbangan dalam melakukan revisi RPP. Saran dari validator terhadap RPP yang dikembangkan yaitu (a) pada kegiatan inti di RPP, perbaiki kata “LKPD” di RPP, ganti semua kata LKPD pada RPP 1 sampai RPP 8 dengan kegiatan yang dilaksanakan, (b) pada KD dan IPK yang ada di RPP belum terdapat indikator mengaitkan di RPP dan seharusnya IPK mengandung banyak indikator bukan hanya satu.

Tabel 5. Hasil Validasi LKPD 
Pengembangan Perangkat Pembelajaran dengan Menggunakan Model Discovery Learning dalam Rangka Memfasilitasi Kemampuan Komunikasi Matematis Pada Materi Bangun Datar Kelas VII SMP, Indah Prestika, Sehatta Saragih, Putri Yuanita

861

\begin{tabular}{|c|l|l|l|l|l|l|l|l|}
\hline & LKPD 1 & LKPD 2 & LKPD 3 & LKPD 4 & LKPD 5 & LKPD 6 & LKPD 7 & LKPD 8 \\
\hline I & $91,89 \%$ & $91,89 \%$ & $91,89 \%$ & $91,89 \%$ & $91,89 \%$ & $91,89 \%$ & $91,89 \%$ & $91,89 \%$ \\
\hline II & $89,18 \%$ & $89,18 \%$ & $89,18 \%$ & $89,18 \%$ & $89,18 \%$ & $89,18 \%$ & $89,18 \%$ & $89,18 \%$ \\
\hline III & $92,56 \%$ & $92,56 \%$ & $92,56 \%$ & $92,56 \%$ & $92,56 \%$ & $92,56 \%$ & $92,56 \%$ & $92,56 \%$ \\
\hline Rata-rata & $91,21 \%$ & $91,21 \%$ & $91,21 \%$ & $91,21 \%$ & $91,21 \%$ & $91,21 \%$ & $91,21 \%$ & $91,21 \%$ \\
\hline
\end{tabular}

Sumber: Olahan data, 2020

Berdasarkan Tabel 5, dapat dilihat bahwa rata-rata nilai validitas masing-masing LKPD memenuhi kriteria sangat valid. Dengan menghitung rata-rata validitas LKPD secara keseluruhan didapatkan nilai validitasnya sebesar 91,21 \% dengan kriteria sangat valid. Meski demikian, saran dan masukan dari validator ditindak lanjuti dengan melakukan revisi terhadap LKPD.Saran dari validator terhadap LKPD yang dikembangkan yaitu penulisan equation yang ada pada LKPD harus diperbaiki dan ganti masalah yang disajikan pada LKPD.Selain itu, validator juga memberikan masukan untuk memberi nama gambar pada setiap gambar yang disajikan pada LKPD.

Tabel 6. Hasil Angket Respon Peserta Didik

\begin{tabular}{|c|l|l|l|l|l|l|}
\hline No & Aspek Penilaian & LKPD 1 & LKPD 2 & LKPD 3 & LKPD 4 & \\
\cline { 1 - 6 } 1 & Materi & $90,74 \%$ & $90,74 \%$ & $92,59 \%$ & $91,66 \%$ \\
\hline 2 & Tampilan & $83,33 \%$ & $86,11 \%$ & $88,88 \%$ & $80,55 \%$ \\
\cline { 1 - 5 } 3 & $\begin{array}{l}\text { Penggunaan } \\
\text { LKPD }\end{array}$ & $88,09 \%$ & $91,66 \%$ & $90,47 \%$ & $89,28 \%$ & \\
\cline { 1 - 5 } No & Aspek Penilaian & LKPD 5 & LKPD 6 & LKPD 7 & LKPD 8 & Rata-Rata \\
\hline 1 & Materi & $89,81 \%$ & $92,59 \%$ & $89,81 \%$ & $89,81 \%$ & $90,97 \%$ \\
\hline 2 & Tampilan & $83,33 \%$ & $91,66 \%$ & $86,11 \%$ & $80,55 \%$ & $85,06 \%$ \\
\hline 3 & $\begin{array}{l}\text { Penggunaan } \\
\text { LKPD }\end{array}$ & $90,47 \%$ & $89,28 \%$ & $91,66 \%$ & $89,28 \%$ & $90,02 \%$ \\
\hline \multicolumn{2}{|l|}{ Rataan Total } & & & & $88,68 \%$ \\
\hline
\end{tabular}

Sumber: Olahan data,2020

Hasil respon peserta didik menunjukkan bahwa seluruh LKPD sudah memenuhi kriteria 88,68 $\%$ sangat praktis. Secara keseluruhan pelaksanaan ujicoba kelompok kecil berjalan lancar. Peserta didik terlihat antusias dalam mengerjakan LKPD yang diberikan oleh peneliti.Masukan dari peserta didik, dalam mengisi jawaban beberapa peserta didik merasa kolom yang disediakan terlalu kecil, sehingga tulisan mereka beberapa ada yang sampai keluar dari kolom yang disediakan.Dari hasil yang diperoleh, peneliti melakukan revisi terhadap LKPD sesuai dengan penilaian dan saran dari hasil uji coba kelompok kecil.

\section{Diskusi}

Penelitian pengembangan merupakan penelitian yang bertujuan untuk menghasilkan suatu produk berupa perangkat pembelajran matematika. Perangkat yang dikembangkan adalah perangkat pembelajaran matematika berbasis model Discovery Learning Dalam Rangka Memfasilitasi Kemampuan Komunikasi Matematis (KKM) peserta didik pada materi Bangun Datar Kelas VII SMP. Perangkat yang dihasilkan berupa Silabus, RPP, dan LKPD.

Tahap pertama yang dilakukan peneliti meliputi tahap analisis yaitu analisis kinerja dan analisis 
kebutuhan. Analisis kinerja dilakukan dengan melakukan wawancara terhadap guru dan menganalisis perangkat pembelajaran guru. Pada tahap ini, peneliti mengkaji kurikulum yang berlaku yaitu kurikulum 2013 melakukan analisis terhadap perangkat pembelajaran yang dibuat guru di sekolah dan masalah yang dihadapi di sekolah dengan teknik wawancara. Aspek wawancara terdiri dari keterlaksanaan Kurikulum 2013, keterlibatan guru dalam menyusun perangkat pembelajaran, mengembangkan IPK, merumuskan tujuan pembelajaran, proses pembelajaran, KKM dan menyusun penilaian hasil belajar. Analisis kebutuhan dilakukan untuk mengkaji masalah dasar yang dihadapi guru dalam proses pembelajaran, khususnya dalam topik bangun datar. Analisis kebutuhan dilakukan dengan cara observasi peserta didik pada saat proses pembelajaran matematika, melakukan wawancara, dan memberikan soal terkait KKM. Peneliti melakukan observasi, tes KKM dan wawancara dengan peserta didik kelas VII SMP. Soal KKM diberikan kepada peserta didik yang telah mempelajari materi bangun datar. Observasi, tes KKM dan wawancara dilakukan untuk melihat aktivitas serta KKM peserta didik terhadap mata pelajaran matematika. Peneliti melakukan analisis dengan cara observasi peserta didik. Berdasarkan hasil observasi terhadap peserta didik diperoleh informasi bahwa keterlibatan peserta didik dalam pembelajaran matematika masih rendah. Dari 30 peserta didik, terdapat 13 orang yang mencatat materi yang dijelaskan guru dan 18 orang yang memperhatikan penjelasan guru. Peserta didik hanya fokus pada guru, apabila mereka menyukai guru tersebut. Peserta didik hanya fokus pada awal pembelajran saja. Peserta didik merasa bahwa catatan dapat dilihat pada buku paket dan melihat punya teman serta dapat bertanya kembali kepada teman yang pintar. Hal ini didapatkan dari wawancara peneliti dengan peserta didik.

Peneliti kemudian menganalisis peserta didik mengenai KKM. Analisis KKM peserta didik dilakukan dengan mencari informasi kepada guru tentang KKM peserta didik selama belajar. Seperti yang diperoleh dari hasil wawancara terhadap guru, hanya sebagian kecil guru yang pernah melakukan tes KKM, dan hasil yang didapatkan bahwa hanya peserta didik yang pandai saja yang mampu menyelesaikan masalah yang diberikan oleh guru. Selain itu, peserta didik bahkan tidak membuat apa yang diketahui dan ditanya dalam suatu masalah. Hal ini menunjukkan rendahnya KKM siswa.

Pada tahap selanjutnya yaitu melakukan tahap design. Pada tahap ini, peneliti merancang perangkat pembelajaran berdasarkan hasil analisis kinerja dan analisis kebutuhan yang telah dilakukan. Perangkat pembelajaran yang dirancang adalah silabus, RPP, dan LKPD. Pada tahap selanjutnya yaitu tahap develop (pengembangan), peneliti mengembangkan perangkat pembelajaran yang sesuai dengan rancangan awal. Perangkat pembelajaran yang dikembangkan kemudian divalidasi oleh tiga orang validator.

Berdasarkan hasil validasi menunjukkan bahwa perangkat pembelajaran yang dikembangkan sangat valid. Rata-rata skor validasi terhadap silabus dari ketiga validator yaitu 85,93\% dengan kategori sangat valid, dengan beberapa pertimbangan aspek penilaian isi dan aspek penilaian kontruksi dengan beberapa indikator penilaian. Hal ini sesuai dengan pendapat Rochmad (2012) mengatakan bahwa validitas dalam suatu penelitian pengembangan meliputi validitas isi dan validitas konstruk. Dalam 
Pengembangan Perangkat Pembelajaran dengan Menggunakan Model Discovery Learning dalam Rangka Memfasilitasi Kemampuan Komunikasi Matematis Pada Materi Bangun Datar Kelas VII SMP, Indah Prestika, Sehatta Saragih, Putri Yuanita

mengembangkan silabus harus memperhatikan perkembangan dan kebutuhan siswa, sistematis dan relevansi, konsistensi dan kecakupannya (Rianti et al., 2020).

Validasi terhadap RPP juga terdiri dari aspek isi dan aspek konstruksi. Hasil validasi RPP dari validator menunjukkan bahwa RPP untuk delapan pertemuan memenuhi kriteria sangat valid dengan persentase rata-rata $88,21 \%$. Validator memberikan saran untuk perbaikan RPP yang dikembangkan. Saran dan masukan yang diberikan validator terhadap RPP yaitu: (1) Pada kegiatan inti di RPP, perbaiki kata "LKPD" di RPP, ganti semua kata LKPD pada RPP 1 sampai RPP 8 dengan kegiatan yang dilaksanakan; (2) Pada KD dan IPK yang ada di RPP belum terdapat indikator mengaitkan di RPP dan seharusnya IPK mengandung banyak indikator bukan hanya satu.

Setelah perangkat direvisi, LKPD diujicobakan pada kelompok kecil untuk melihat kepraktisan peserta didik terhadap LKPD yang dikembangkan. Uji coba kepraktisan dilakukan kepada 12 orang peserta didik kelas VII SMP Dharma Yudha Pekanbaru. Berdasarkan hasil validasi terhadap LKPD, rata-rata skor validasi terhadap LKPD dari ketiga validator yaitu 91,21\% dengan kriteria sangat valid dengan beberapa aspek penilaian yaitu tampilan sampul LKPD, isi, kesesuaian dengan syarat didaktis, konstruksi dan teknis. Hal ini sesuai dengan pendapat Revita (2017) dan Anugraheni (2018) dalam penelitiannya menyatakan bahwa syarat yang menjadikan LKPD sebagai bahan ajar yang baik ditinjau dari aspek didaktik, aspek isi, aspek bahasa serta aspek penyajian dan waktu. Secara keseluruhan, LKPD yang peneliti kembangkan sudah memenuhi semua aspek tersebut, namun terdapat beberapa saran dari validator untuk perbaikan pada LKPD. Beberapa saran perbaikan pada LKPD adalah penulisan equation yang ada pada LKPD harus diperbaiki dan ganti masalah yang disajikan pada LKPD, selain itu validator juga memberikan masukan untuk memberi nama gambar pada setiap gambar yang disajikan pada LKPD.

Tahap keempat adalah tahap implementation. Pada penelitian ini peneliti hanya melakukan ujicoba sampai skala kecil untuk melihat kepraktisan LKPD yang digunakan oleh peserta didik, hal ini dikarenakan mewabahnya COVID-19 di Pekanbaru sehingga membuat peneliti tidak bisa melakukan ujicoba skala besar untuk melihat keterlaksanaan sesuai rancangan perangkat pembelajaran yang dikembangkan. Setelah melakukan ujicoba skala kecil untuk melihat kepraktisan LKPD menggunakan angket respon peserta didik. Berdasarkan angket respon peserta didik maka peserta didik menyatakan bahwa LKPD yang dikembangkan dapat membantu peserta didik dalam memahami permasalahan dan menyelesaikan permasalahan bangun datar dalam kehidupan sehari-hari. Hal ini sesuai dengan fungsi LKPD menurut Prastowo bahwa LKPD ini dapat mempermudah peserta didik dalam memahami materi yang diberikan (Rianti et al., 2020), (MZ et al., 2019). Selanjutnya LKPD yang diberikan sudah baik dan terperinci sehingga dapat membantu semua peserta didik untuk menemukan rumus dan menyelesaikan masalah pada materi bangun datar (Putra et al., 2018), (Hasmawati et al., 2019).

Hasil respon peserta didik pada tahap ujicoba terbatas ini menunjukkan bahwa LKPD dinilai sudah sangat praktis dengan persentase rata-rata 88,68\%. Pada saat ujicoba dilakukan, peneliti menemukan beberapa hal yang perlu direvisi pada LKPD, diantaranya kotak penulisan dalam LKPD yang kecil sehingga menyulitkan peserta didik untuk menulisnya. Dari masukan tersebut peneliti 
melakukan revisi pada LKPD sesuai dengan hasil yang peneliti peroleh selama kegiatan pembelajaran pada saat ujicoba kelompok kecil. Niveen menyatakan bahwa perangkat pembelajaran dikatakan memiliki kualitas yang baik apabila perangkat tersebut valid, dan praktis (Novrini et al., 2015). Berdasarkan hasil validasi terhadap silabus, RPP, dan LKPD untuk materi bangun ruang dapat disimpulkan bahwa perangkat pembelajaran yang dikembangkan telah memenuhi kriteria kevalidan. Berdasarkan lembar respon peserta didik terhadap penggunaan LKPD dapat disimpulkan bahwa LKPD yang dikembangkan telah memenuhi kriteria kepraktisan.

\section{KESIMPULAN}

Berdasarkan hasil penelitian dan pengembangan yang telah diuraikan diperoleh beberapa simpulan (1) produk pengembangan berupa perangkat pembelajaran matematika dengan model pembelajaran discovery learning dalam rangka memfasilitasi kemampuan komunikasi matematis pada materi bangun datar telah memenuhi kriteria validitas dengan kategori valid; (2) Produk pengembangan berupa perangkat pembelajaran matematika dengan model pembelajaran discovery learning dalam rangka memfasilitasi kemampuan komunikasi matematis pada materi bangun datar telah memenuhi kriteria kepraktisan dengan tingkat kepraktisan berada pada kategori sangat praktis.

\section{UCAPAN TERIMA KASIH}

Pada kesempatan ini penulis mengucapkan terima kasih dan penghargaan yang sebesarbesarnya kepada:

1. Bapak Prof. Dr. Ir Thamrin, M. Sc selaku Direktur Program Pascasarjana Universitas Riau.

2. Ibu Dra. Yenita Roza, Ph. D selaku koordinator Program Studi yang telah banyak membantu dan mengarahkan dan membimbing penulis selama menjadi mahasiswa Program Studi Magister Pendidikan Matematika Program Pascasarjana Universitas Riau.

3. Bapak Dr. Sehatta Saragih, M. Pd selaku Ketua Komisi Pembimbing dan Ibu Dr. Putri Yuanita, M. Ed selaku anggota Komisi Pembimbing, yang telah banyak meluangkan waktu untuk membimbing, mengarahkan penulis mulai awal penelitian hingga selesainya penyusunan tesis ini.

4. Seluruh Bapak dan Ibu dosen yang telah memberikan ilmu pengetahuannya kepada penulis selama menjadi mahasiswa di Program Magister Pendidikan Matematika.

5. Kepada Orang Tua, Saudara, dan Teman-teman yang telah dengan sabar dan penuh semangat memberikan motivasi kepada penulis mulai awal perkuliahan hingga selesai penyusunan tesis ini.

Akhir kata semoga karya akhir ini dapat bermanfaat bagi dunia pendidikan dan pihak terkait dengan penelitian ini serta memicu munculnya penelitian-penelitian yang lain untuk kemajuan ilmu pengetahuan dimasa mendatang, Atas perhatian dan bantuan seluruh pihak diucapkan terima kasih. 
Pengembangan Perangkat Pembelajaran dengan Menggunakan Model Discovery Learning dalam Rangka Memfasilitasi Kemampuan Komunikasi Matematis Pada Materi Bangun Datar Kelas VII SMP, Indah Prestika, Sehatta Saragih, Putri Yuanita

\section{REFERENSI}

Akbar, S. (2013). Instrumen Perangkat Pembelajaran. PT Remaja Rosdakarya.

Anugraheni, I. (2018). Pengembangan Perangkat Pembelajaran Matematika Berbasis Pendidikan Karakter Kreatif Di Sekolah Dasar. Jurnal Refeleksi Edukatika, 8(2), 132-138. https://doi.org/10.24176/re.v8i2.2351

Ferawati. (2020). Pengembangan Perangkat Pembelajaran Matematika Berbasis Contextual Teaching and Learning pada SMK Swasta di Kabupaten Tangerang. Prosiding Seminar Nasional Dan Diskusi Panel Pendidikan Matematika Universitas Indraprasta PGRI Jakarta, 43, 47-56.

Hadi, S. (2018). Penerapan Pembelajaran Kooperatif Jigsaw terhadap Peningkatan Kemampuan Komunikasi dan Pemecahan Masalah Matematika Siswa Smp Swasta Lombok Timur. Jurnal Pendidikan Mandala, 3(3), 1-8.

Hasmawati, Sumarna, N., Hamid, R., \& Ili, L. (2019). Mengembangkan Penalaran Matematis Melalui Lembar Kerja Peserta Didik (LKPD) Berbasis Masalah Pada Siswa Kelas V SDN 2 Kendari. Jurnal Wahana Kajian Pendidikan IPS, 3(2), 35-45. https://doi.org/dx.doi.org/10.33772/JWKPIPS

Kartika, Y., Hutapea, N. M., \& Kartini. (2020). Mathematical Learning Development using Discovery Learning Model to Improve Mathematical Understanding Skills of Students. Journal of Educational Sciences, 4(1), 124-132. https://doi.org/10.31258/jes.4.1.p.124-132

Kaselin, Sukestiyarno, \& Waluya, B. (2013). Kemampuan Komunikasi Matematis Pada Pembelajaran Matematika dengan Strategi React Berbasis Etnomatematika. Unnes Journal of Research Mathematics Education, 2(2), 121-127.

Kemendikbud. (2013). Peraturan Menteri Pendidikan dan Kebudayaan Republik Indonesia Nomor 65 Tahun 2013 tentang standar Proses Pendidikan Dasar dan Menengah. Kemendikbud.

Mukaromah, D., Sugiyo, \& Mulawarman. (2018). Keterlibatan Siswa dalam Pembelajaran ditinjau dari Efikasi Diri dan Self Regu- lated Learning. Indonesian Journal of Guidance and Counseling: Theory and Application, 7(2), 14-19. journal.unnes.ac.id/sju/index.php/jbk

MZ, Z. A., Anggraini, F., Kusnadi, \& Alfiah. (2019). Pengembangan Lembar Kerja Peserta Didik (LKPD) Matematis Berbasis PBL Terintegrasi Nilai-Nilai Islam di Sekolah Dasar Islam Terpadu. JMIE: Journal of Madrasah Ibtidaiyah Education, 3(2), 168-178. http://journal.uinalauddin.ac.id/index.php/PendidikanFisika/article/view/3143

Novrini, N., Siagian, P., \& Surya, E. (2015). Pengembangan Perangkat Pembelajaran Berorientasi Problem Based Learning untuk Meningkatkan Kemampuan Visual Thinking dalam Pemecahan Masalah Matematis Siswa Kelas VIII SMP. Paradikma Jurnal Pendidikan Matematika, 8(3). 
Nuraeni, R., \& Luritawaty, I. P. (2018). Mengembangkan Kemampuan Komunikasi Matematik Siswa melalui Strategi Think Talk Write. Mosharafa: Jurnal Pendidikan Matematika, 5(2), 101-112. https://doi.org/10.31980/mosharafa.v5i2.265

Putra, A., Syarifuddin, H., \& Zulfah, Z. (2018). Validitas Lembar Kerja Peserta Didik Berbasis Penemuan Terbimbing dalam Upaya Meningkatkan Pemahaman Konsep dan Kemampuan Penalaran Matematis. Edumatika Jurnal Riset Pendidikan Matematika, 1(2), 56-62. https://doi.org/10.32939/ejrpm.v1i2.302

Revita, R. (2017). Validitas Perangkat Pembelajaran Matematika Berbasis Penemuan Terbimbing. Suska Journal of Mathematics Education, 3(1), 15. https://doi.org/10.24014/sjme.v3i1.3425

Rianti, R., Saragih, S., \& Zulkarnain. (2020). Pengembangan Perangkat Pembelajaran Matematika Dalam Konteks Budaya Melayu Riau Untuk Meningkatkan Kemampuan Pemecahan Masalah Matematis Peserta Didik. Journal Of Educational Sciences, 4(1), 73-82.

Rochmad. (2012). Desain Model Pengembangan Perangkat Pembelajaran Matematika. Kreano, Jurnal Matematika Kreatif-Inovatif, 3(1), 59-72.

Suharno, Sulistiawati, \& Arifin, S. (2019). Pengaruh Metode Thinking Aloud Pair Problem Solving (TAPPS) terhadap Kemampuan Komunikasi Matematis Siswa SMP Negeri 1 Manggar. Numeracy Journal, 6(1), 166-176.

Yuliyanto, \& Jailani. (2014). Pengembangan Perangkat Pembelajaran Geometri SMP Menggunakan Metode Penemuan Terbimbing Pada Kelas VIII Semester II. Jurnal Riset Pendidikan Matematika, 1(1), 127-138. https://doi.org/10.21831/jrpm.v1i1.2670 